\title{
Dideoxy Single Allele-Specific PCR - DSASP New Method to Discrimination Allelic
}

\author{
Eleonidas Moura Lima ${ }^{1,2 *}$, Otávio Sérgio Lopes $^{3}$, Leonardo Ferreira Soares ${ }^{4}$, Talitta \\ Dantas Arruda $^{2}$, Carolina Oliveira Gigek ${ }^{5}$, Cynthia Germoglio Farias Melo ${ }^{2}$, Marilia \\ Arruda Cardoso Smith ${ }^{5}$, João Ricardo Gonçalves Oliveira ${ }^{2}$, Arnaldo Medeiros ${ }^{6}$, Plínio \\ Delatorre $^{2}$ and Rommel Rodriguez Burbano ${ }^{7}$ \\ ${ }^{1}$ Departamento de Biologia Molecular; Universidade Federal da Paraíba; João Pessoa - PB - Brasil. ${ }^{2}$ Laboratório \\ de Biologia Molecular Estrutural e Oncogenética; Universidade Federal da Paraíba; João Pessoa - PB - Brasil. \\ ${ }^{3}$ Departamento de Dermatologia; Clinica Dermatológica Santa Catarina; João Pessoa - PB - Brasil. \\ ${ }^{4}$ Departamento de Farmácia; Universidade Estadual da Paraíba; Campina Grande - PB - Brasil. ${ }^{5}$ Departamento de \\ Genética de Morfologia; Universidade Federal de São Paulo; São Paulo - SP - Brasil. ${ }^{6}$ Departamento de Medicina; \\ Universidade Federal da Paraíba; João Pessoa - PB - Brasil. ${ }^{7}$ Instituto de Ciências Biológicas; Universidade \\ Federal do Pará; Belém - PA - Brasil
}

\begin{abstract}
Gastric cancer $(G C)$ is a multifactorial disease with a high mortality rate in Brazil and worldwide. This work aimed to evaluate single nucleotide polymorphisms (SNP) rs1695, in the Glutathione S-Transferase Pi (GSTP1) gene in GC samples by comparative analysis Specific PCR - ASP and Dideoxy Single Allele-Specific PCR - DSASP methods. The DSASP is the proposed new method for allelic discrimination. This work analyzed 60 GC samples, 26 diffuse and 34 intestinal types. The SNP rs1695 of the GSTP1 gene was significantly associated with GC analyzed by DSASP method $\left(\chi^{2}=9.7, P<0.05\right)$. A comparative analysis of the data obtained from both methods did not differ significantly $\left(\chi^{2}=0.08, P>0.05\right)$. These results suggest that the SNP rs1695 of the GSTP1 gene was a risk factor associated with gastric carcinogens is and the DSASP method was a new successfully low-cost strategy to study allelic discrimination.
\end{abstract}

Key words: DSASP method, genotyping, Gastric Cancer

\section{INTRODUCTION}

The gastric cancer (GC) is a multifactorial disease involving genetic, epigenetic and environmental factors, including diet, chronic atrophic gastritis, radiation exposure and infection by Helicobacter pylori. It is the fourth most common type of cancer and the second most common cancer related cause of death in the world population (Khan et al. 2005; Crew and Neugut 2006; Jemal et al. 2011).
With the completion of the Human Genome Project, a large number of subtle variations (polymorphisms) among the population have been found (Sachidanandam et al. 2001; Collins et al. 2003). The most abundant type of these variations is single nucleotide polymorphisms (SNPs), with more than nine million reported in public databases. The SNPs are a single nucleotide variation at a specific location in the genome that is by definition found in more than $1 \%$ of the population (Brookes 1999; Rocha et al. 2006).

\footnotetext{
*Author for correspondence: eleonidas@pq.cnpq.br
} 
SNPs have been described as responsible for genetic predisposition for several complex diseases (Nunokawa et al. 2010; Giusti et al. 2010; Heinzen et al. 2010). The are studies on establishing the association of certain SNPs with different behaviors of cancer cells in various types of tumors in an attempt to determine molecular markers (Gao et al. 2014; Lui et al. 2014; Tengström et al. 2014).

SNPs in the genes that encod enzymes involved in the biotransformation of carcinogens have also been linked to GC development. The genes of the family of glutathione S-transferase (GST) seem relevant to cancer susceptibility (Miller et al. 2002).

The Glutathione S-Transferase Pi (GSTPI) gene, mapping of chromosomal region 11q13, and encoding the isoenzyme $\mathrm{P} 1$ participates in the metabolism of halogenated compounds, molecules of low molecular weight reactive epoxides of some with polycyclic aromatic hydrocarbons (PAHs) (Islami et al. 2012).

Due to the importance of the SNPs analysis, methods for analyzing allelic discrimination, in particular methods based on the primer extension, have been developed, wich include Allele-Specific PCR (ASP) method involving PCR amplification of genomic DNA using allele-specific primers that are labeled differently and a common reverse primer (Gibbs et al. 1989).

Single Base Extension (SBE) method, consisting in designing the primers before the polymorphic position of interest and an embedded ddNTP specific such as, Mass spectrometry-based detection, MassEXTEND ${ }^{\mathrm{tm}}$ (Haff and Smirnov 1997; Ross et al. 1998), and fluorescence detection, which uses a primer that anneals one base upstream of the SNP site followed by its extension with ddNTPs that are labeled with different fluorescent tags. Products are detected by fluorescence after capillary electrophoresis and the color of dye indicates incorporated base(s) and hence the SNP genotype (Sokolov 1990; Le et al. 2002).

The DSASP method, which is based on the work of Sanger et al. (1977), is a new strategy for the analysis of allelic discrimination. DSASP method is based upon incorporation of ddNTP predicted in specific positions relative to the SNP of interest. In this study, the SNP rs1695 of the GSTP1 gene in GC samples previously analyzed by ASP method (Araújo et al. 2014) was analyzed by DSASP method.
The DSASP method has some peculiarity, as in PCR only one strand of DNA is amplified, since only one primer is used. Also in the PCR, three different deoxynucleotides and one specific dideoxynucleotide are added. After amplification, the PCR product is hybridized to its complementary sequence previously defined and synthesized.

The design of primer in the DSASP method takes into account the position of the SNP of interest in relation to the preceding nucleotides and the position of incorporation of the specific dideoxynucleotides before and after the SNP of interest. The PCR amplification product is hybridized to its complementary sequence to perform allelic discrimination by amplification of fragments of different sizes or different melting temperatures $(\mathrm{Tm})$, each fragment or $\mathrm{Tm}$ corresponds to its specific allele.

\section{MATERIAL AND METHODS}

\section{Samples}

The present study analyzed 60 samples of GC from the samples in the Laboratory of Molecular and Structural Biology Oncogenetics (LBMEO). The samples were is composed of 26 cases of diffuse-types GC and 34 intestinal types according to the classification of Laurén (1965) and were obtained with the patients' consent. The study was previously approved by the University Hospital João of Barros Barreto and Hospital of Clinics of Faculty of Medicine of RibeirãoPreto ethics committee. All tissues were frozen in liquid nitrogen immediately after tumor ressection and stored at $-80^{\circ} \mathrm{C}$. Genomic DNA isolated by proteinase $\mathrm{K}$ digestion and phenol-chloroform extraction methods and stored at $-20^{\circ} \mathrm{C}$ according to the method described by Rey et al. (1992).

\section{Method Dideoxy Single Allele-Specific PCR - DSASP}

To detect the SNP rs1695 (A>G) of the GSTPI gene DSASP method involving specific primer with specific characteristics, and sequence complementary to the hybridization step. These sequences were obtained by in silico validation (Software GeneRunner).

The primer and the complementary sequence for DSASP genotyping were designed following the manufacturers' recommendations. For genotyping the SNP rs1695 $(\mathrm{A}>\mathrm{G})$ of the GSTPl gene by 
DSASP, the primer designed considered the position of incorporation of the specific dideoxynucleotide (ddGTP) upstream seven nucleotides and downstream 23 nucleotides in relation to $S N P$ of interest. Only one primer was used in the PCR and a set of nucleotides comprising ddGTP and dATP, dCTP, and dTTP. The complementary sequence corresponded to 45 nucleotides used in the hybridization step. Then, the PCR amplification product was hybridized with its complementary sequence. As a result, the $\mathrm{G}$ allele corresponded to the amplification of a 38nucleotides fragment and $\mathrm{Tm}: 52^{\circ} \mathrm{C}$ and $\mathrm{A}$ allele corresponded to the amplification of a 45nucleotides fragment and $\mathrm{Tm}: 65^{\circ} \mathrm{C}$. Therefore, the alleles were discriminated specifically by presenting different $\mathrm{Tm}$, which could melting curve analysis by qPCR (Fig.1).

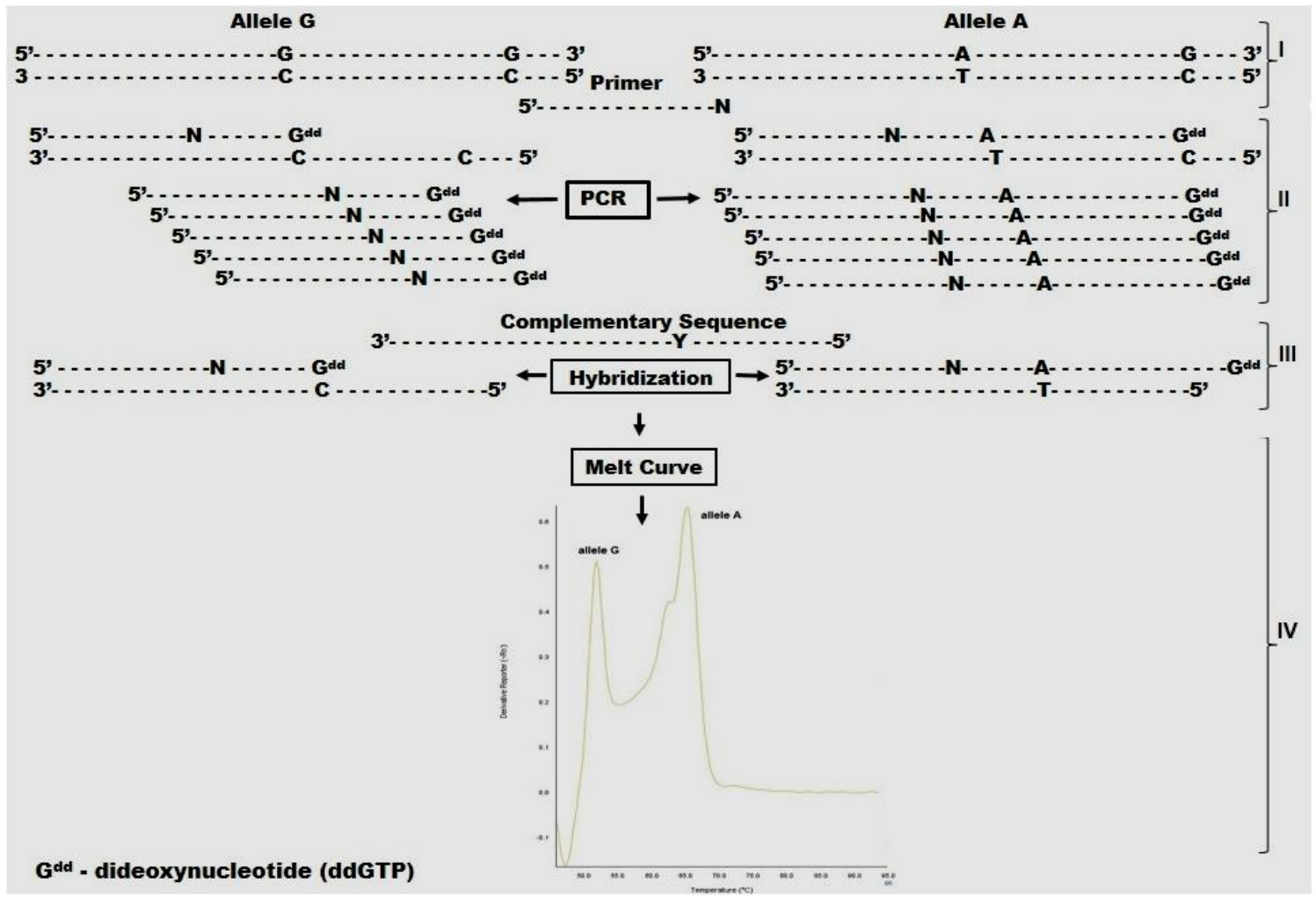

Figure 1 - The stages of DSASP method for analysis of SNP rs1695 in GSTP1 gene: I - the SNP selection and design of the primer; II - PCR with one primer and dideoxynucleotide of interest; III - hybridization reaction with the specific complementary sequence and IV melting curve analysis by qPCR.

\section{Validation in silico}

The primers used for DSASP of the SNP rs1695 $(\mathrm{A}>\mathrm{G})$ of the GSTP1 gene were designed based on the database Ensembl Genome Browser and using the Gene Runner program (Table 1) to evaluate the annealing temperature, the formation of secondary structure and size of the amplified fragments.

Table 1 - Primer and complementary sequence for genotyping of SNP rs1695 of the GSTP1 gene by DSASP method.

\begin{tabular}{cl}
\hline SNP & Primer / Complementary Sequence - CS \\
\hline rs1695 & F1: 5'-GGTGATGACGGCRTGGAGGACCTCCGCTG-3' \\
& CS: 5'-AGGGAGAYGTATTTGCAGCGGAGGTCCTCCAYGCCGTCATTCACC-3' \\
\hline
\end{tabular}

\section{PCR Conditions}

PCR was performed in a final volume of $25 \mu \mathrm{L}$ containing $200 \mu \mathrm{M}$ dNTP (dATP, dCTP, dTTP and ddGTP), $2.0 \mathrm{mM} \mathrm{MgCl} 2,20 \mathrm{ng} / \mu \mathrm{L}$ DNA, 200

$p \mathrm{M}$ primer and $0.5 \mathrm{U}$ AmpliTaq Gold (Life Technologies - Carlsbad, CA). PCR conditions for 
amplification of single stranded DNA were as follows: a pre-denaturation for $3 \mathrm{~min}$ at $94^{\circ} \mathrm{C}$ and 80 cycles of $94^{\circ} \mathrm{C}$ for $20 \mathrm{~s}$ of $50^{\circ} \mathrm{C}$ for $45 \mathrm{~s}$ and $72^{\circ} \mathrm{C}$ for $30 \mathrm{~s}$ with a final extension of $5 \mathrm{~min}$ at $72^{\circ} \mathrm{C}$.

\section{Hybridization conditions}

The product of the PCR amplification of each sample was subjected to hybridization step under the following conditions: $200 \mathrm{pM}$ of the complementary sequence at $4^{\circ} \mathrm{C}$ for $10 \mathrm{~min}$.

\section{Melting Curve Analysis}

The melting curve were analysed to determine the Tm performed by Real Time PCR equipment 7500 Fast Real-Time PCR System (Life Technologies Carlsbad, CA) following the conditions: preheat starting at $25^{\circ} \mathrm{C}$ to $95^{\circ} \mathrm{C}$ for $1 \mathrm{~min}$, folding up to $45^{\circ} \mathrm{C}$ for $5 \mathrm{~min}$ and gradual heating $\left(1^{\circ} \mathrm{C} \min \right)$ until a temperature of $95^{\circ} \mathrm{C}$ for $5 \mathrm{~min}$. For melting curve analysis, $\mathrm{SYBR}^{\circledR}$ Green Mix (Life Technologies - Carlsbad, CA) was used.

\section{Statistical Analysis}

To evaluate the prognostic and predictive values of the SNP rs1695 of the GSTP1 gene in gastric cancer samples obtained by DSASP method analyzes of Hardy-Weinberg and Chi-square test were carried out using the statistical program R. The results ware considered statistically significant $\mathrm{P} \leq 0.05$.

The results obtained by DSASP method were validated by comparison with results obtained by Allele Specific PCR - ASP (Araújo et al. 2014) for the same SNP and the same sample using the Chisquare test using the $\mathrm{R}$ statistical program considered non-significant $P>0.05$.

\section{RESULTS AND DISCUSSION}

The allelic frequencies the SNP rs1695 of in GSTP1 gene obtained by the DSASP were 0.74 and 0.26 for the $A$ and $G$ alleles, respectively, with the following genotype distribution: $46.7 \%(\mathrm{n}=$ 28) $\mathrm{A} / \mathrm{A}(\mathrm{Ile} / \mathrm{Ile}), 53.3 \%(\mathrm{n}=32) \mathrm{A} / \mathrm{G}(\mathrm{Ile} / \mathrm{Val})$ and $0 \%(\mathrm{n}=0) \mathrm{G} / \mathrm{G}(\mathrm{Val} / \mathrm{Val})($ Table 2$)$ with $\chi^{2}=$ 9.70. Second statistical analysis shows this sampleis not in Hardy- Weinberg equilibrium ( $\mathrm{P}<$ $0.05)$. Samples showed only genotypes $A / A$ and A/G. A melting temperature of $65^{\circ} \mathrm{C}$ for A allele (Fig.2) and $52^{\circ} \mathrm{C}$ for $\mathrm{G}$ allele (Fig.3) was observed.
Table 2 - Results of the allelic frequencies and genotype distribution of SNP rs1695 of the GSTP1 gene obtained by DSASP method.

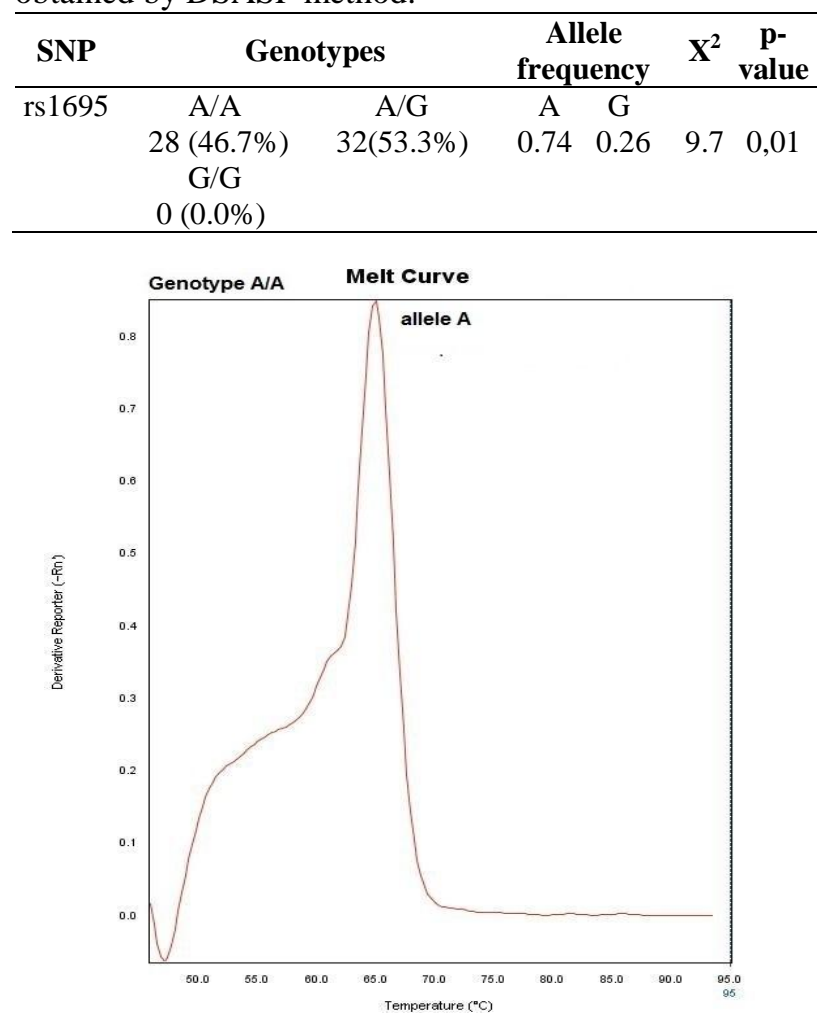

Figure 2 - Genotype A/A of SNP rs1695 of the GSTP1 gene determined by DSASP method by melting curve analysis with $\mathrm{Tm} 65^{\circ} \mathrm{C}$ for $\mathrm{A}$ allele.

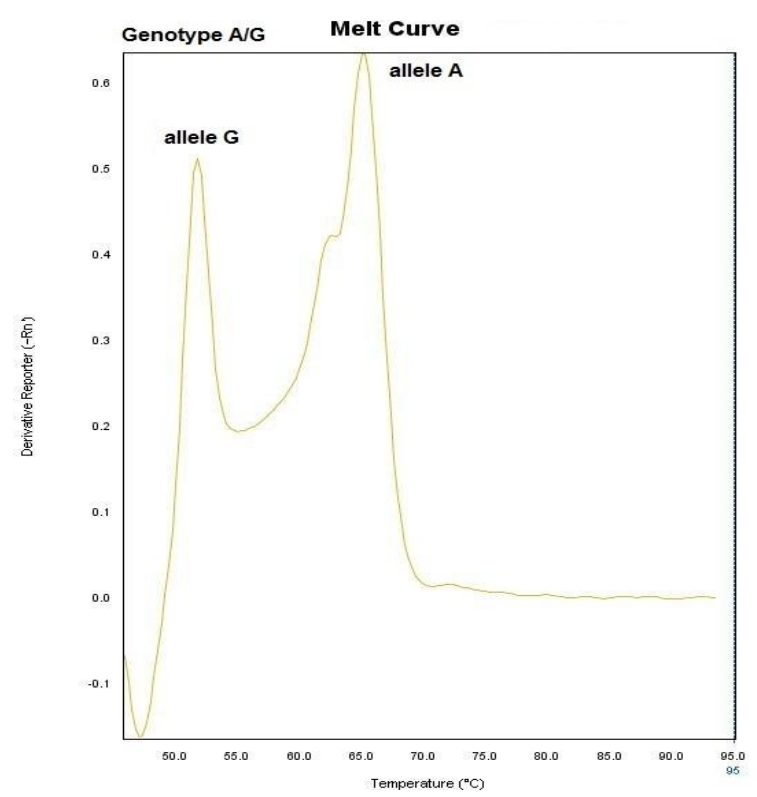

Figure 3 - Genotype A/G of SNP rs1695 of the GSTP1 gene determined by DSASP method by melting curve analysis with $\mathrm{Tm} 52^{\circ} \mathrm{C}$ for $\mathrm{G}$ allele and $\mathrm{Tm} 65^{\circ} \mathrm{C}$ for A allele. 
The data obtained by Araújo et al. (2014) by ASP method for allelic frequencies of the SNP rs 1695 of in GSTP1 gene were 0.73 and 0.27 for the A and $G$ alleles, respectively, with the following genotype distribution: $45 \%(\mathrm{n}=27) \mathrm{A} / \mathrm{A}(\mathrm{Ile} / \mathrm{Ile})$, $55 \%(\mathrm{n}=33) \mathrm{A} / \mathrm{G}(\mathrm{Ile} / \mathrm{Val})$ and $0 \%(\mathrm{n}=0) \mathrm{G} / \mathrm{G}$ (Val/Val) (Table 3).

The SNP rs1695 of in GSTP1 gene were significantly associated with GC in the samples analyzed $\left(\chi^{2}=8.73, \mathrm{P}<0.05\right)$.

Table 3 - Results of the allelic frequencies and genotype distribution of SNP rs1695 of the GSTP1 gene obtained by ASP method by.

\begin{tabular}{|c|c|c|c|c|c|}
\hline SNP & \multicolumn{2}{|c|}{ Genotypes } & \multicolumn{2}{|c|}{$\begin{array}{c}\text { Allele } \\
\text { frequency }\end{array}$} & $\begin{array}{c}\text { p- } \\
\text { value }\end{array}$ \\
\hline rs1695 & $\begin{array}{c}\mathrm{A} / \mathrm{A} \\
27(45 \%) \\
\mathrm{G} / \mathrm{G} \\
0(0.0 \%)\end{array}$ & $\begin{array}{c}\mathrm{A} / \mathrm{G} \\
33(55 \%)\end{array}$ & $\begin{array}{c}\mathrm{A} \\
0.73\end{array}$ & $\begin{array}{l}\mathrm{G} \\
0.278 .73\end{array}$ & 0,01 \\
\hline
\end{tabular}

The comparative analysis between the data obtained by Araújo et al. (2014) by the ASP method with data obtained by the DSASP method did not significantly differ $\left(\chi^{2}=0.08, P>0.05\right)$, as expected.

Carcinogenesis may be due to the defects in the mechanisms associated with the protection of cellular damage caused by xenobiotics. Among these mechanisms, there is population variability in the frequency of polymorphisms in the genes for detoxification / metabolism. The GSTP1 gene encodes an enzyme that acts as a carcinogen detoxication and has been described as a "guardian" gene because it actively protects the cell from oxidative damage mediated by carcinogenic components (Suvakov et al. 2013).

Dunna et al. (2012) studied the SPN rs1695 in 290 patients with acute leukemia, 147 with acute lymphocytic leukemia (ALL) and 143 with acute myeloid leukemia (AML) and 248 healthy people. The observed genotypes differed significantly among the three groups, with 51 and $10.9 \%$ of the genotypes $\mathrm{A} / \mathrm{G}$ and $\mathrm{G} / \mathrm{G}$ in LLA, in AML 44.8 and $18.9 \%$ of the genotypes $\mathrm{A} / \mathrm{G}$ and $\mathrm{G} / \mathrm{G}$, while the control group showed 42.3 and $1.2 \%$ of the genotypes $A / G$ and $\mathrm{G} / \mathrm{G}$, respectively. These results suggested that the $\mathrm{G} / \mathrm{G}$ genotype was a risk for the development of ALL and AML factor was also associated with poor prognosis (Dunna et al. 2012).

Ibarrola-Villava et al. (2012) analyzed the samples from 562 Spanish patients with sporadic malignant melanoma (MM) and 338 cancer-free control. This was the first time that the GSTP1 rs1695 polymorphism was reported to be associated with MM. In addition, this study was one of the largest GST polymorphism studies undertaken in the Spanish population and the first time that copy number variants were scrutinized in relation to MM (Ibarrola-Villava et al. 2012).

The analysis of SNPs rs1695 and rs2853676 of GSTP1 and Telomerase Reverse Transcriptase (TERT) genes respectively in 301 samples and 302 control samples Gliomas in Chinese patients showed a positive association for susceptibility to develop this neoplasm, therefore, could be considered risk factors for development gliomas (Li et al. 2012).

$\mathrm{Gu}$ et al. (2014) analyzed the SNP rs7208693 of the Myeloperoxidase - MPO gene and haplotype SNPs rs1695, rs4891, rs762803 and rs749174 of the GSTP1 gene in 266 samples of lung câncer and 307 controls without personal history of the disease were recruited in this study in Chinese Han population. Haplotype SNPs rs1695, rs4891, rs762803 and rs749174 of the GSTP1 gene exhibited an association with lung cancer susceptibility in smokers in the overall population and in the studied subgroups but not the MPO SNP rs7208693 (Gu et al. 2014).

$\mathrm{Xu}$ et al. (2012) studied 929 diagnostic GC patients in China and found a positive association between the SNPs rs1695 of the GSTP1 gene and rs4880 of the SOD2 gene to gastric carcinogenesis in this population. However, García-González et al. (2012), who studied the SNP rs1695 in 557 patients originating from southern Europe as GC, observed no association of this SNP with susceptibility to gastric cancer in this population (García-González et al. 2012).

The analysis of SNP rs1695 in 60 samples of GC patients from Northern Brazil by ASP method showed a positive association between the polymorphism in question and the development of intestinal-type gastric cancer, corroborating the findings of $\mathrm{Xu}$ et al. (2012) and Araújo et al. (2014).

The same samples analyzed by Araújo et al. (2014) using the ASP method were used to validate the DSASP method. The results obtained by the method DSASP were statistically different. Therefore, the results obtained by the method DSASP ratified the findings of Araújo et al. (2014). 


\section{CONCLUSION}

The DSASP method could be a low-cost strategy for the studies on allelic discrimination, and theoretically could analyze any SNP of interest. In relation to the ASP method, it costed about half per sample. The DSASP method compared with other methods such as SBE, Fluorescence detection or MassEXTEND ${ }^{\mathrm{tm}}$ methods, appeared advantageous because it was performed with the reagentes and equipments of low cost. Therefore, DSASP method could be a new low-cost strategy to study allelic discrimination.

\section{ACKNOWLEDGEMENTS}

This work was supported by grants of CAPES and CNPq. The authors would like to thank Jimmy Johnson for proofreading the article.

\section{REFERENCES}

Araújo RM, Melo CF, Neto FM, Silva JN, Soares LF, Arruda Cardoso Smith M, et al. Association study of SNPs of genes IFNGR1 (rs137854905), GSTT1 (rs71748309), and GSTP1 (rs1695) in gastric cancer development in samples of patient in the northern and northeastern Brazil. Tumour Biology. 2014; 35(5): 4983-4986.

Brookes AJ. The essence of SNPs. Gene. 1999; 234: 177-186.

Collins FS, Morgan M, Patrinos A. The Human Genome Project: lessons from large-scale biology. Science. 2003; 300: 286-290.

Crew KD, Neugut AI. Epidemiology of gastric cancer. World J Gastroenterol. 2006; 12: 354-362.

Dunna NR, Vuree S, Kagita S, Surekha D, Digumarti $\mathrm{R}$, Rajappa S, et al. Association of GSTP1 gene (I105V) polymorphism with acute leukaemia. $J$ Genet. 2012; 91(1):e60-63.

Gao X, Mi Y, Yan A, Sha B, Guo N, Hu Z, et al. The PHLDB1 rs498872 (11q23.3) polymorphism and glioma risk: A meta-analysis. Asia Pac J Clin Oncol. 2014; doi: 10.1111/ajco.12211.

García-González MA, Quintero E, Bujanda L, Nicolás D, Benito R, Strunk M, et al. Relevance of GSTM1, GSTT1, and GSTP1 gene polymorphisms to gastric cancersusceptibility and phenotype. Mutagenesis. 2012; 27(6):771-777.

Gibbs RA, Nguyen PN, Caskey CT. Detection of single DNA base dif- ferences by competitive oligonucleotide priming. Nucleic Acids Res. 1989; 17: 2437-2448.
Giusti B, Gori AM, Marcucci R, Abbate R. Relation of CYP2C19 loss-of-function polymorphism to the occurrence of stent thrombosis. Expert Opin Drug Metab Toxicol. 2010; 6(4): 393-407.

Gu JD, Hua F, Mei CR, Zheng DJ, Wang GF, Zhou QH. HapMap-based study on the association between MPO and GSTP1 gene polymorphisms and lung cancer susceptibility in Chinese Han population. Acta Pharmacol Sin. 2014; 35(5):636-644.

Haff LA, SmirnovI P. Single-nucleotide polymorphism identification assays using a thermostable DNA polymerase and delayed extraction MALDI- TOF mass spectrometry. Genome Res. 1997; 7: 378-388.

Heinzen EL; Need AC, Hayden KM, Chiba-Falek O, Roses AD, Strittmatter WJ, et al. Genome-wide scan of copy number variation in late-onset Alzheimer's disease. J Alzheimers Dis. 2010; 19 (1): 69-77.

Ibarrola-Villava M, Martin-Gonzalez M, Lazaro P, Pizarro A, Lluch A, Ribas G. Role of glutathione Stransferases in melanoma susceptibility: association with GSTP1 rs1695 polymorphism. Br J Dermatol. 2012; 166(6): 1176-1183.

Islami F, Boffetta P, van Schooten FJ, Strickland P, Phillips DH, Pourshams A, et al. Exposure to Polycyclic Aromatic Hydrocarbons Among Never Smokers in Golestan Province, Iran, an Area of High Incidence of Esophageal Cancer - a Cross-Sectional Study with Repeated Measurement of Urinary 1OHPG in Two Seasons. Front Oncol. 2012; 2: 14.

Jemal A, Bray F, Center MM, Ferlay J, Ward E, Forman D. Global cancer statistics. CA Cancer J Clin. 2011; 61: 69-90.

Khan MI, Baqai MT, Bukhari M, Hashmi RI. Gastric carcinoma: 5 years survival after gastric surgery. $J$ Pak Med Assoc. 2005; 55: 158-160.

Lauren P. The Two Histological Main Types of Gastric Carcinoma: Diffuse and So-Called Intestinal-Type Carcinoma. An Attempt at a Histo-Clinical Classification. Acta Pathol Microbiol Scand. 1965; 64: 31-49.

Le Hellard S, Ballereau SJ, Visscher PM, Torrance HS, Pinson J, Morris SW, et al. SNP genotyping on pooled DNAs:comparison of genotyping Technologies and a semi automated method for data storage and analysis. Nucleic Acids Res. 2002; 30: 74.

Li G, Jin TB, Wei XB, He SM, Liang HJ, Yang HX, et al. Selected polymorphisms of GSTP1 and TERT were associated with glioma risk in Han Chinese. Cancer Epidemiol. 2012; 36(6):525-527.

Liu P, Shi H, Yang Y, Liu R, Huang C, Shu H, et al. Update meta-analysis on $1790 \mathrm{G} / \mathrm{A}$ polymorphism and câncer risk: Evidence from 26 studies. Neoplasma. 2014; 61(3): 340-351.

Miller DP, Liu G, De Vivo I, Lynch TJ, Wain JC, Su L, et al. Combinations of the variant genotypes of GSTP1, GSTM1, and p53 are associated with an increased lung cancer risk. Cancer Res. 2002; 62: 2819-2823. 
Nunokawa A, Watanabe Y, Kaneko N. Sugai T, Yazaki $\mathrm{S}$, Arinami $\mathrm{T}$, et al. The dopamine D3 receptor (DRD3) gene and risk of schizophrenia: case-control studies and an updated meta-analysis. Schizophr Res. 2010; 116 (1): p.61-67.

Rey JA, Bello MJ, Jimenez-Lara AM, Vaquero J, Kusak ME, de Campos JM, et al. Loss of heterozygosity for distal markers on $22 \mathrm{q}$ in human gliomas. Int J Cancer. 1992; 51: 703-706.

Rocha D, Gut I, Jeffreys AJ, Kwok PY, Brookes AJ, Chanock SJ. Seventh international meeting on single nucleotide polymorphism and complex genome analysis: "ever bigger scans and an increasingly variable genome." Hum Genet. 2006; 119: 451-456.

Ross P, Hall L, Smirnov I, Haff L. High level multiplex genotyping by MALDI-TOF mass spectrometry. Nat Biotechnol. 1998; 16: 1347-1351.

Sachidanandam R, Weissman D, Schmidt SC, Kakol JM, Stein LD, Marth G, et al. A map of human genome sequence variation containing 1.42 million single nucleotide polymorphisms. Nature. 2002; 409:928-933.

Sanger F, Nicklen S, Coulson AR. DNA sequencing with chain-terminating inhibitors. Proc Natl Acad Sci U S A. 1977; 74(12): 5463-5467.
Sokolov BP. Primer extension technique for the detection of single nucleotide in genomic DNA. Nucleic Acids Res. 1990; 18: 3671.

Suvakov S, Damjanovic T, Stefanovic A, Pekmezovic T, Savic-Radojevic A, Pljesa-Ercegovac M, et al. Glutathione S-transferase A1, M1, P1 and T1 null or low-activity genotypes are associated with enhanced oxidative damage among haemodialysis patients. Nephrol Dial Transplant. 2013; 28(1): 202-212.

Tengström M, Mannermaa A, Kosma VM, Hirvonen A, Kataja V. XRCC1 rs25487 polymorphism predicts the survival of patients after postoperative radiotherapy and adjuvant chemotherapy for breast cancer. Anticancer Res. 2014; 34(6): 3031-3037.

$\mathrm{Xu} \mathrm{Z,} \mathrm{Zhu} \mathrm{H,} \mathrm{Luk} \mathrm{JM,} \mathrm{Wu} \mathrm{D,} \mathrm{Gu} \mathrm{D,} \mathrm{Gong} \mathrm{W,} \mathrm{et} \mathrm{al.}$ Clinical significance of SOD2 and GSTP1 gene polymorphisms in Chinese patients withgastric cancer. Cancer. 2012; 118(22):5489-5496.

Received: December 10, 2014; Accepted: March 12, 2015. 